This document was prepared in conjunction with work accomplished under Contract No. DE-AC09-96SR18500 with the U. S. Department of Energy.

\title{
DISCLAIMER
}

This report was prepared as an account of work sponsored by an agency of the United States Government. Neither the United States Government nor any agency thereof, nor any of their employees, nor any of their contractors, subcontractors or their employees, makes any warranty, express or implied, or assumes any legal liability or responsibility for the accuracy, completeness, or any third party's use or the results of such use of any information, apparatus, product, or process disclosed, or represents that its use would not infringe privately owned rights. Reference herein to any specific commercial product, process, or service by trade name, trademark, manufacturer, or otherwise, does not necessarily constitute or imply its endorsement, recommendation, or favoring by the United States Government or any agency thereof or its contractors or subcontractors. The views and opinions of authors expressed herein do not necessarily state or reflect those of the United States Government or any agency thereof. 


\section{PREPARATION AND HEAT-TREATMENT OF DWPF SIMULANTS WITH AND WITHOUT CO-PRECIPITATED NOBLE METALS}

David C. Koopman

Russell E. Eibling

August 2005

Immobilization Technology Section Savannah River National Laboratory Aiken, SC 29808

Prepared for the U.S. Department of Energy Under Contract Number DEAC09-96SR18500
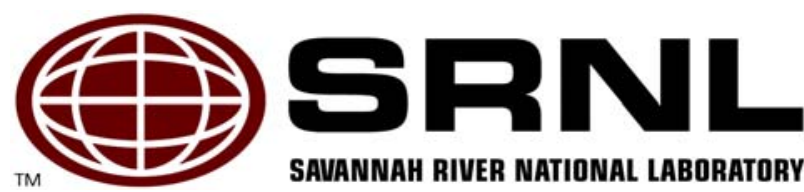

SAUANNAH RIVER NATIONAL LABORATORY 


\section{DISCLAIMER}

This report was prepared by Westinghouse Savannah River Company (WSRC) for the United States Department of Energy under Contract No. DE-AC09-96SR18500 and is an account of work performed under that contract. Neither the United States Department of Energy, nor WSRC, nor any of their employees makes any warranty, expressed or implied, or assumes any legal liability or responsibility for the accuracy, completeness, or usefulness, of any information, apparatus, or product or process disclosed herein or represents that its use will not infringe privately owned rights. Reference herein to any specific commercial product, process, or service by trademark, name, manufacturer or otherwise does not necessarily constitute or imply endorsement, recommendation, or favoring of same by WSRC or by the United States Government or any agency thereof. The views and opinions of the authors expressed herein do not necessarily state or reflect those of the United States Government or any agency thereof.

\section{Printed in the United States of America}

Prepared For U.S. Department of Energy 
WSRC-TR-2005-00285

Revision 0

Key Words: Simulant Development, Noble Metals, DWPF

Retention: permanent

\section{PREPARATION AND HEAT-TREATMENT OF DWPF SIMULANTS WITH AND WITHOUT CO-PRECIPITATED NOBLE METALS}

David C. Koopman

Russell E. Eibling

August 2005

Immobilization Technology Section Savannah River National Laboratory Aiken, SC 29808

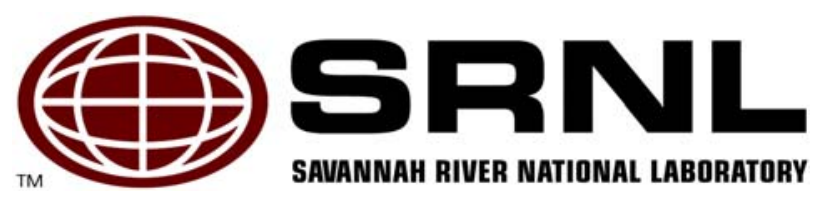




\section{REVIEWS AND APPROVALS}

\section{AUTHORS:}

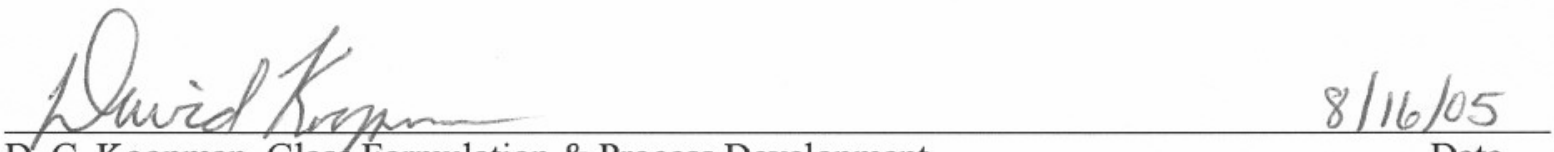

D. C. Koopman, Glaş Formulation \& Process Development

\section{TECHNICAL REVIEWERS:}

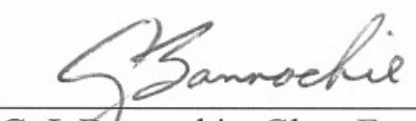

C. J.Bannochie, Glass Formulation \& Process Development
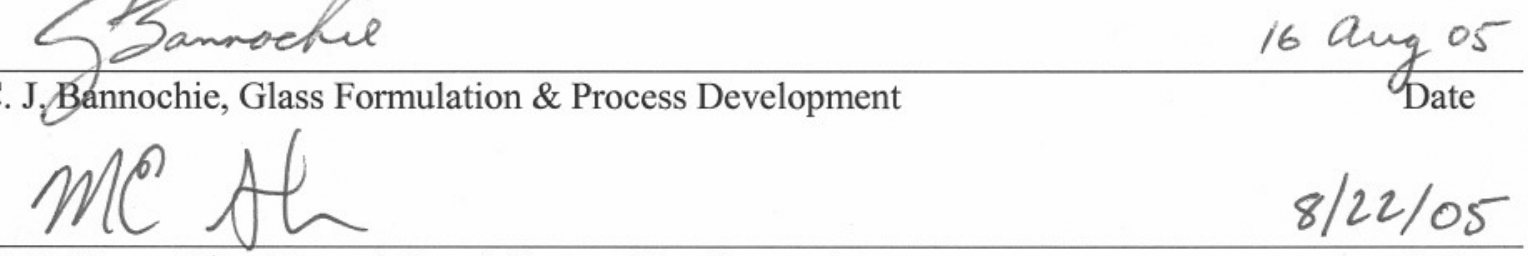

M. E. Stone, Glass Formulation \& Process Development

$8 / 22 / 05$

\section{APPROVERS:}

\section{Enthetzahule}

E. W. Holtzscheiter, Manager, Immobilization Technology Section

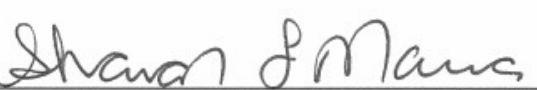

S. L. Marra, Manager, Glass Formulation \& Process Development
$8 / 22 / 05$ Date

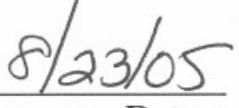

Date

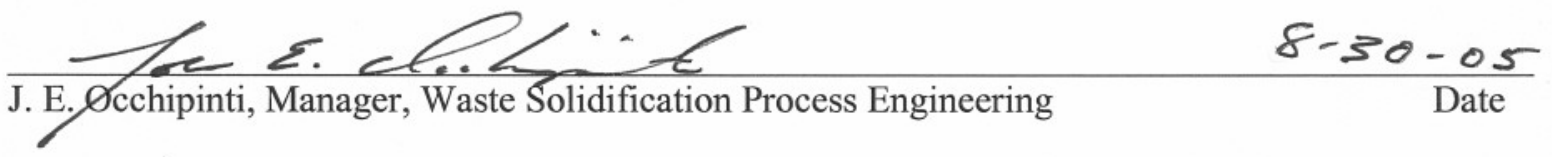




\section{EXECUTIVE SUMMARY}

The Savannah River National Laboratory is in the process of investigating factors suspected of impacting catalytic hydrogen generation in the Chemical Process Cell of the Defense Waste Processing Facility, DWPF. Noble metal catalyzed hydrogen generation in simulation work constrains the allowable acid addition operating window in DWPF. This constraint potentially impacts washing strategies during sludge batch preparation. It can also influence decisions related to the addition of secondary waste streams to a sludge batch. Noble metals have historically been added as trim chemicals to process simulations. The present study investigated the potential conservatism that might be present from adding the catalytic species as trim chemicals to the final sludge simulant versus co-precipitating the noble metals into the insoluble sludge solids matrix.

Parallel preparations of two sludge simulants targeting the composition of Sludge Batch 3 were performed in order to evaluate the impact of the form of noble metals. Identical steps were used except that one simulant had dissolved palladium, rhodium, and ruthenium present during the precipitation of the insoluble solids. Noble metals were trimmed into the other stimulant prior to process tests. Portions of both sludge simulants were held at $97^{\circ} \mathrm{C}$ for about eight hours to qualitatively simulate the effects of long term storage on particle morphology and speciation. The simulants were used as feeds for Sludge Receipt and Adjustment Tank, SRAT, process simulations.

The following conclusions were drawn from the simulant preparation work:

- The first preparation of a waste slurry simulant with co-precipitated noble metals was successful, based on the data obtained. It appears that $99+\%$ of the noble metals were retained in the simulant.

- Better control of carbonate, hydroxide, and post-wash trim chemical additions is needed before the new method of simulant preparation will be as reproducible as the old method.

- The two new simulants were visually very viscous compared to the traditional SB3 simulant.

- Heat-treatment reduced the viscosity of the two new simulants with and without coprecipitated noble metals, though they were still more viscous than the traditional SB3 simulant.

- The approach of using a $97^{\circ} \mathrm{C}$ heat-treatment step to qualitatively simulate tank farm aging may not be optimal. A significant change in the base equivalent molarities of both simulants was observed during heat-treatment.

- Heat-treatment appeared to make phosphates insoluble in water.

The following recommendations came out of the work:

- Washed slurry should be checked for TIC and base equivalents before calculating the final trim chemical additions of sodium carbonate and sodium hydroxide.

- Final insoluble trim chemicals should be added to the slurry in the cross-flow filtration unit mixing tank, since significant slurry is lost in the CUF equipment. Adding the chemicals here would keep them in the correct proportion relative to the precipitated insoluble solids.

- A composite wash and decant sample should be prepared containing proportionally weighted masses of each aqueous stream removed during preparation of a co-precipitated noble metal simulant. This sample should then be checked for noble metal losses. This would reduce the sample load, while still confirming that there was no significant noble metal loss. 
- A study of the impact of heat-treatment on existing simulants should be undertaken. If there is a shift in base equivalents, then SRNL acid stoichiometries may be biased relative to real waste. The study should be extended to several real wastes as well. 


\section{TABLE OF CONTENTS}

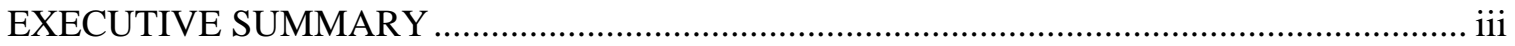

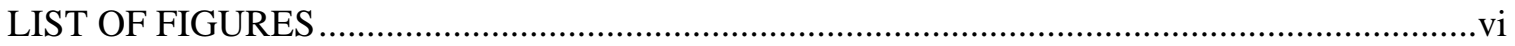

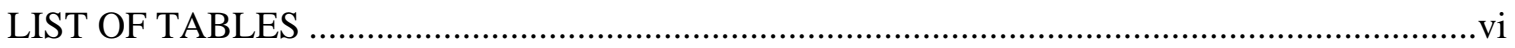

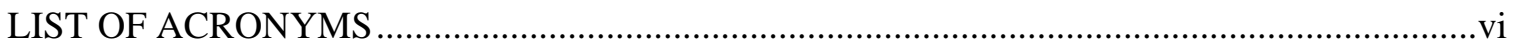

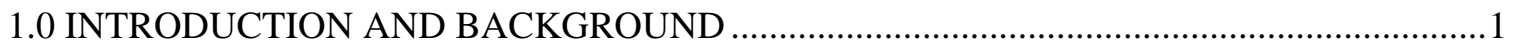

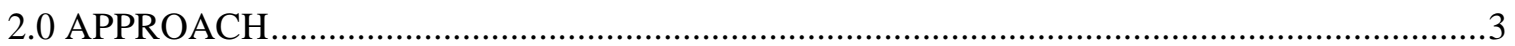

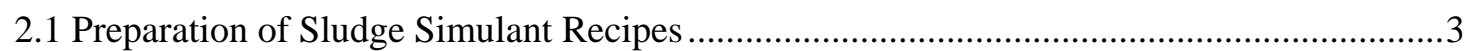

2.2 Equipment Used in Simulant Preparation .....................................................................4

2.3 Analytical Methods and Controls for Sample Characterization...........................................4

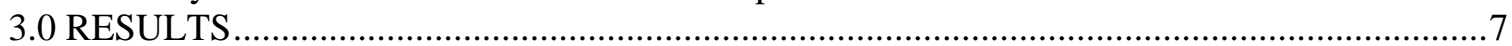

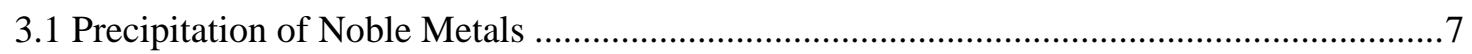

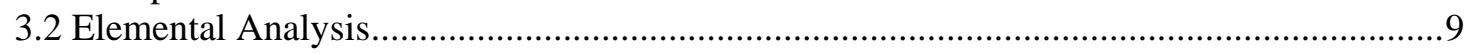

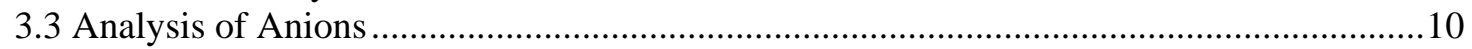

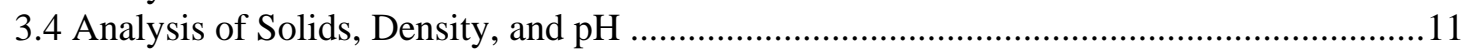

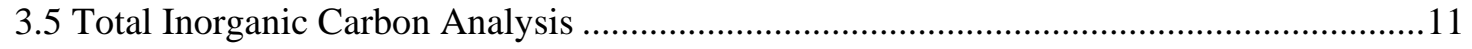

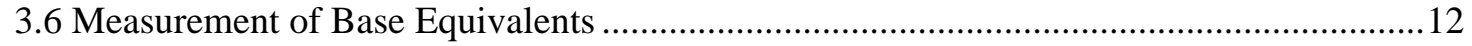

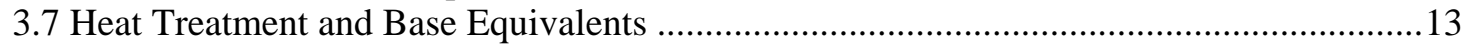

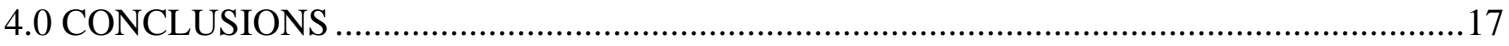

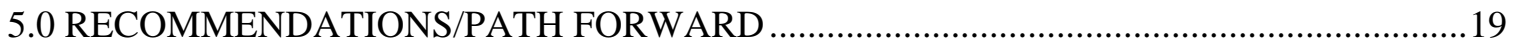

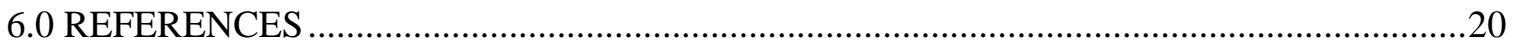

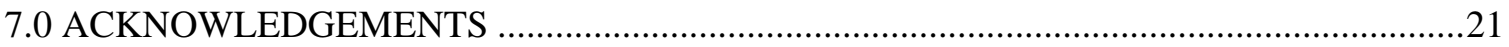




\section{LIST OF FIGURES}

Figure 1. Heat-Treatment Titration Data Summary ........................................................................ 14

Figure 2. Effect of Heat-treatment at Alternate pH Endpoints ........................................................ 15

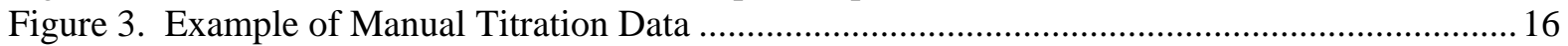

\section{LIST OF TABLES}

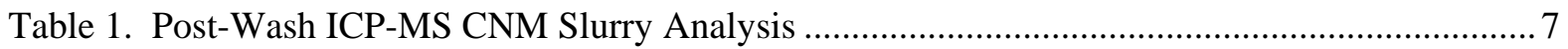

Table 2. Noble Metal Concentrations in Removed Aqueous Streams ................................................ 8

Table 3. Bounding Noble Metal Mass Losses During Sludge Preparation ........................................... 8

Table 4. Final CNM Slurry Noble Metal Analysis.............................................................................

Table 5. Calcined Elemental Composition of the Starting Sludges................................................... 10

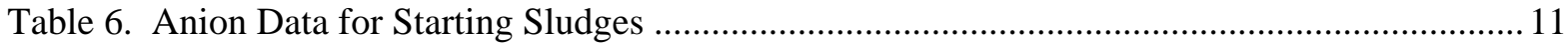

Table 7. Wt. \% Solids, Density, and pH Data for Starting Sludges ................................................ 11

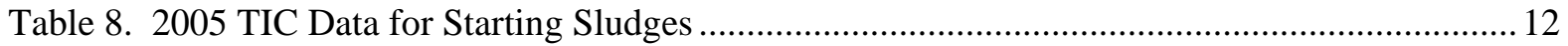

Table 9. Base Equivalents Measurements on Starting Slurries ...................................................... 12

\section{LIST OF ACRONYMS}

$\begin{array}{ll}\text { ACTL } & \text { Aiken County Technical Laboratory } \\ \text { ADS } & \text { Analytical Development Section } \\ \text { ASP } & \text { Analytical Study Plan } \\ \text { CNM } & \text { Co-precipitated Noble Metal simulant } \\ \text { CPC } & \text { Chemical Process Cell } \\ \text { CUF } & \text { Cross-flow Filtration Unit } \\ \text { DWPF } & \text { Defense Waste Processing Facility } \\ \text { GPD } & \text { Glass Formulation and Process Development group } \\ \text { HT } & \text { Heat-treated } \\ \text { IC } & \text { Ion Chromatography } \\ \text { ICP-AES } & \text { Inductively Coupled Plasma-Atomic Emission Spectroscopy } \\ \text { ICP-MS } & \text { Inductively Coupled Plasma-Mass Spectroscopy } \\ \text { ITS } & \text { Immobilization Technology Section } \\ \text { SB3 } & \text { Sludge Batch 3 (the combination of “SB3" with the heel of SB2) } \\ \text { SRAT } & \text { Sludge Receipt and Adjustment Tank } \\ \text { SRS } & \text { Savannah River Site } \\ \text { SRNL } & \text { Savannah River National Laboratory } \\ \text { TIC } & \text { Total Inorganic Carbon } \\ \text { TNM } & \text { Trimmed Noble Metal simulant } \\ \text { TR } & \text { Technical Report } \\ \text { TT\&QAP } & \text { Task Technical and Quality Assurance Plan } \\ \text { TTR } & \text { Task technical request } \\ \text { WSRC } & \text { Westinghouse Savannah River Company }\end{array}$




\subsection{INTRODUCTION AND BACKGROUND}

The Defense Waste Processing Facility, DWPF, has requested that the Savannah River National Laboratory, SRNL, investigate the factors that contribute to hydrogen generation to determine if current conservatism in setting the DWPF processing window can be reduced. SRNL testing constrains the acid addition window in the DWPF Sludge Receipt and Adjustment Tank, SRAT, to avoid the region of excessive hydrogen generation. Such constraints can alter decisions about the extent of washing required for a new sludge batch. They can also impact decisions concerning the addition of lesser waste streams to an existing sludge batch.

Work commenced upon receipt of the DWPF task technical request, HLW/DWPF/TTR-04-0028. A task technical and quality assurance plan, TT\&QAP, was prepared, Fellinger (2004). An analytical study plan was prepared, Koopman (2005a). A phased program was developed to increase understanding of the factors that influence hydrogen generation in the DWPF Chemical Process Cell, CPC.

Phase I included the following activities and was divided into three parts:

Part 1 Issue the $\mathrm{H}_{2}$ generation literature review covering work through 2002, i.e. through Sludge Batch 2. This has now been reported in WSRC-TR-2002-00034. Analyze some 1998 data found during the review. Update the review to cover Sludge Batch 2/3 and Sludge Batch 3, SB3, hydrogen generation data collected to date. This is reported in WSRC-TR2005-00206.

Part 2 Document recent FY04 scoping tests performed with different forms of $\mathrm{Hg}$. WSRC-TR2004-00548 has been issued.

Part 3 Obtain a SB3 simulant from the Simulant Development Program without noble metals. Modify a SB3 recipe from the Simulant Development Program to include noble metals. This simulant, with co-precipitated noble metals, will be used to test the impact of the form of noble metals on hydrogen generation. The results of this preparation are reported herein.

Phase II includes the following activities and is divided into two parts:

Part 1 Perform SRAT cycles to determine any impact of the form of noble metals on $\mathrm{H}_{2}$ generation in the SRAT. This is reported in WSRC-TR-2005-00286.

Part 2 Follow-up form of noble metal work, including an assessment to determine if similar hydrogen production is achieved using simulants in the Shielded Cells equipment setup used in the SB3 qualification effort. This work is on-going.

The impact of the form of noble metals was factor was the primary emphasis of the experimental portion of the FY05 phase of the hydrogen generation program. Previous simulant studies have trimmed the noble metals into the available sludge simulant at the desired target compositions for $\mathrm{Pd}, \mathrm{Rh}$, and $\mathrm{Ru}$.

Part 3 of the first phase of the hydrogen generation program was to prepare a simulant of SB3 slurry containing co-precipitated noble metals. The simulant targeted an existing preparation of SB3 slurry without noble metals produced by the Simulant Development Program, Eibling (2005). The second goal was to compare the analytical results of the two simulants. Any justifiable adjustments were to be made 
to make them as similar as possible. Portions of both simulants were heat-treated to qualitatively simulate aging in the tank farm. This created a set of four SB3 simulants:

- As-made, no noble metals added

- As-made, with co-precipitated noble metals

- Heat-treated, with no noble metals added

- Heat-treated, with co-precipitated noble metals

Preparation and characterization of these simulants is the subject of this report. 


\subsection{APPROACH}

SB3 simulant represents the current feed to DWPF. SB3 also represents a relatively less washed sludge than previously studied. It also has higher noble metal concentrations than either Sludge Batch 1A or 1B. SRNL began an investigation into the relationship between simulant preparation and simulant properties, Eibling (2005). This investigation has continued in parallel with the hydrogen generation program. The simulant preparation method was selected as the basis for the hydrogen generation program form of noble metals testing work, because of the established processing characteristics described in Eibling (2005).

\subsection{Preparation of Sludge Simulant Recipes}

SRNL has developed the capability to produce small quantities $(<20 \mathrm{~L})$ of DWPF sludge feed simulants at ACTL. A 10-L batch targeting the composition of SB3 was prepared by the Simulant Development Program in FY04. This batch did not include either $\mathrm{Hg}$ or the noble metals $\mathrm{Pd}, \mathrm{Rh}$, and $\mathrm{Ru}$. This simulant was part of an effort to better understand how simulant preparation methodology affects simulant processing properties, Eibling (2005). Generally similar equipment was used to prepare the SB3 recipe a second time, but with noble metals present during precipitation. Both simulants targeted the SB3 Tank 40 analyses in Pareizs (2004).

The general procedure used in preparing these simulants is given below

1. Target values were developed from the analysis of a Tank 40 sample of actual SB3 feed.

2. A target size was selected for the recipe (about $11 \mathrm{Kg}$ ).

3. Insoluble $\mathrm{MnO}_{2}$ was precipitated by combining $\mathrm{KMnO}_{4}$ and $\mathrm{Mn}\left(\mathrm{NO}_{3}\right)_{2}$ in aqueous solution.

4. $\mathrm{Fe}\left(\mathrm{NO}_{3}\right)_{3} \cdot 9 \mathrm{H}_{2} \mathrm{O} ; \mathrm{Ni}\left(\mathrm{NO}_{3}\right)_{2} \cdot 6 \mathrm{H}_{2} \mathrm{O} ; \mathrm{ZrO}\left(\mathrm{NO}_{3}\right)_{2} \cdot \mathrm{xH}_{2} \mathrm{O}, \mathrm{x} \sim 6 ; \mathrm{Ce}\left(\mathrm{NO}_{3}\right)_{3} \cdot 6 \mathrm{H}_{2} \mathrm{O} ; \mathrm{Gd}\left(\mathrm{NO}_{3}\right)_{3} \cdot \mathrm{XH}_{2} \mathrm{O}, \mathrm{X} \sim 6$; $\mathrm{La}\left(\mathrm{NO}_{3}\right)_{3} \cdot 6 \mathrm{H}_{2} \mathrm{O} ; \mathrm{Ba}\left(\mathrm{NO}_{3}\right)_{2} ; \mathrm{Ca}\left(\mathrm{NO}_{3}\right)_{2} \cdot 4 \mathrm{H}_{2} \mathrm{O} ; \mathrm{Cd}\left(\mathrm{NO}_{3}\right)_{2} \cdot 4 \mathrm{H}_{2} \mathrm{O} ; \mathrm{Cr}\left(\mathrm{NO}_{3}\right)_{3} \cdot 9 \mathrm{H}_{2} \mathrm{O} ; \mathrm{Cu}\left(\mathrm{NO}_{3}\right)_{2} \cdot 2.5 \mathrm{H}_{2} \mathrm{O}$; $\mathrm{Mg}\left(\mathrm{NO}_{3}\right)_{2} \cdot 6 \mathrm{H}_{2} \mathrm{O} ; \mathrm{Pb}\left(\mathrm{NO}_{3}\right)_{2} ; \mathbf{P d}\left(\mathrm{NO}_{3}\right)_{2}$ solution @ 15.27 wt\% Pd; $\mathbf{R h}\left(\mathbf{N O}_{3}\right)_{3}$ solution @ 4.933 wt\%

Rh; RuCl 3 @ 41.74 wt\% Ru; $\mathrm{Sr}\left(\mathrm{NO}_{3}\right)_{2} ; \mathrm{Zn}\left(\mathrm{NO}_{3}\right)_{2} \cdot 6 \mathrm{H}_{2} \mathrm{O} ; \mathrm{Sb}_{2} \mathrm{O}_{3}$; and $\mathrm{AgNO}_{3}$ were added to the dilute $\mathrm{MnO}_{2}$ slurry.

5. The $\mathrm{pH}$ was taken to 9 using a 50:50 mixture of $50 \mathrm{wt}$. \% $\mathrm{NaOH}$ solution and de-ionized water.

6. The slurry was then contacted with a $0.6 \mathrm{M}$ sodium carbonate solution.

7. The slurry was decanted and then washed with inhibited water until the nitrate content was below $2000 \mathrm{mg} / \mathrm{kg}$.

8. The washed slurry volume and wt. \% total solids were adjusted so that the remaining additions would produce an appropriate wt. \% total solids level and have the proper supernate concentrations.

9. $\mathrm{TiO}_{2}, \mathrm{SiO}_{2}, \mathrm{SnO}_{2}$, and $\mathrm{Al}_{2} \mathrm{O}_{3}$ were added.

10. The mass and density were checked.

11. $\mathrm{KNO}_{3}, \mathrm{~K}_{2} \mathrm{MoO}_{4}, \mathrm{H}_{3} \mathrm{BO}_{3}, \mathrm{LiOH} \cdot \mathrm{H}_{2} \mathrm{O}, \mathrm{Na}_{2} \mathrm{C}_{2} \mathrm{O}_{4}, \mathrm{NaCl}, \mathrm{NaF}, \mathrm{Na}_{2} \mathrm{SO}_{4} \cdot \mathrm{Na}_{3} \mathrm{PO}_{4} \cdot 12 \mathrm{H}_{2} \mathrm{O}, \mathrm{NaOH}, \mathrm{Na}_{2} \mathrm{CO}_{3}$, $\mathrm{NaNO}_{2}$, and $\mathrm{NaNO}_{3}$ were added.

12. Samples were submitted for analyses.

The three noble metals, $\mathrm{Pd}, \mathrm{Rh}$, and $\mathrm{Ru}$, were only added during step 4 during production of the simulant with co-precipitated noble metals. Both simulants were prepared with $\mathrm{Ag}$ and without $\mathrm{Hg}$. This was expected to lead to the maximum hydrogen generation rate for a given acid addition strategy based on the experimental work in the initial phase of the hydrogen generation program, Koopman (2005b). 


\subsection{Equipment Used in Simulant Preparation}

The testing was performed at the Aiken County Technology Laboratory, ACTL. There were two phases to simulant preparation. The first phase involved successful completion of a simulant recipe. The second phase involved applying a heat-treatment step to a completed simulant. The heat-treatment step was performed to qualitatively simulate the effects of long term storage on the particle morphology and chemical speciation in Savannah River Site wastes. Heat is the standard substitute for time when there is a need to accelerate certain chemical and physical processes.

The physical equipment for preparing a simulant recipe consisted of a vessel about 20-25 liters in size, equipped with an agitator and a $\mathrm{pH}$ probe. Temperature was not controlled. Washed SRS waste simulants containing co-precipitated noble metals had not been prepared before. There was concern that the noble metals might not co-precipitate as part of the sludge matrix, but might instead precipitate onto the process equipment surfaces. As a precaution, polyethylene carboys with specially fluorinated, i.e. Teflon-like, interior surfaces were selected for the precipitation vessel. A plastic agitator shaft equipped with plastic blades was used for the mixing as a precaution. Metal agitator shafts and blades had been observed to discolor during some SRAT simulations. This may or may not be due to noble metals.

The equipment for washing the precipitated sludge solids consisted of a stainless steel mixing vessel mounted above a pump which circulated liquid through a cross-flow filtration unit, CUF. Slurry was returned to the mixing vessel, while permeate was withdrawn. An adjustable rate positive displacement pump was used to meter inhibited water into the mixing vessel at approximately the same rate that permeate was withdrawn from the cross-flow filter.

Heat-treatment of completed simulants was performed on about three liters of simulant at a time. A 4-L glass vessel similar to those used in lab scale SRAT simulations was used. It was mounted in a heating mantle. The vessel was covered with a lid. A mixer and thermocouple were mounted through the lid into the slurry. The thermocouple was connected to a controller that regulated the power to the heating mantle. A reflux condenser was mounted on the lid to condense moisture evaporating from the slurry and return it to the vessel. A recirculating chiller set at $5-10^{\circ} \mathrm{C}$ was connected to the reflux condenser.

Slurry was taken to $96-98^{\circ} \mathrm{C}$ and held there for 7-8 hours to perform a heat-treatment. The simulant with co-precipitated noble metals was heat-treated first. A decision was made to heat-treat a portion of the simulant without noble metals when it was found that heat-treatment had changed the inputs to the stoichiometric acid calculation for the SRAT cycle, see Koopman (2005b). A smaller portion of coprecipitated noble metal simulant was heat-treated to investigate the rate at which the base equivalents of the slurry was changing with time.

There were two issues with simulant preparation related to TIC and to base equivalents that will be discussed further in the Results section. Both slurries were much thicker at 18-19 wt. \% total solids than SB3 simulants prepared from the Clemson Environmental Technologies Laboratory, CETL, simulants. CETL simulants have been used in the SB3 and preliminary SB4 flowsheet and melt rate studies. Eibling (2005) indicated that cross-flow filtration had an effect on simulant rheology and particle size.

\subsection{Analytical Methods and Controls for Sample Characterization}

Analyses followed the guidance in the Analytical Study Plan, Koopman (2004a). Sample request forms were submitted along with the samples to be analyzed. A unique lab identification number was assigned to each sample for tracking purposes. Analyses were performed using approved analytical and QA procedures. 
Samples were taken of the four versions of SB3 simulant:

- As-made, with no noble metals

- As-made, with co-precipitated noble metals

- Heat-treated, with no noble metals

- Heat-treated, with co-precipitated noble metals

Samples were analyzed by the ITS Mobile Lab, by ITS-ACTL, and by the SRNL-Analytical Development Section, ADS.

The Mobile Lab performed analyses on the sludge slurries to determine the chemical composition, total and dissolved solids, density, and $\mathrm{pH}$. The chemical composition was determined in duplicate by calcining the samples at $1100^{\circ} \mathrm{C}$ and then dissolving the product using $\mathrm{Na}_{2} \mathrm{O}_{2} / \mathrm{NaOH}$ fusion and lithium metaborate fusion with acid uptake of the fusions. The preparations were then analyzed using Inductively Coupled Plasma - Atomic Emission Spectroscopy, ICP-AES, to measure the cations present. Anion concentrations were determined by Ion Chromatography, IC. Slurries were diluted with de-ionized water and then filtered before injection into the IC. The total solids were measured on two aliquots of each slurry sample. The dissolved solids were measured on two supernate aliquots obtained from filtered slurry. The insoluble and soluble solids fractions were calculated from the total and dissolved solids results.

ADS analyzed samples of the sludge and various supernate streams by Inductively Coupled Plasma-Mass Spectroscopy, ICP-MS, to monitor noble metals during preparation of the co-precipitated noble metal simulant. Slurry samples were subjected to an aqua regia dissolution before analysis by ICP-MS. ADS also analyzed samples of the sludge to determine the total inorganic carbon, TIC, content.

ITS-ACTL performed the base equivalents titration on the starting sludge samples to provide the necessary input for the acid calculation. Early results were obtained by auto-titrator using $0.1 \mathrm{M} \mathrm{HCl}$ and a 30:1 dilution of the sample. Titration measurements switched to a manual titration technique using $1 \mathrm{M}$ $\mathrm{HNO}_{3}$ solution and a 10:1 dilution of the sample after the auto-titrator failed in the middle of the program.

It was necessary to develop a manual titration method that gave similar results to the auto-titrator. Initial manual titrations were performed on a set of five samples with previously measured base equivalents from the auto-titrator. The initial titrations were done on undiluted slurry. Many issues of reproducibility and variation from expected values arose during these titrations. The $\mathrm{pH}$ readings were frequently very slow to stabilize once the $\mathrm{pH}$ was below 7.5. The manual titration method evolved through several iterations until a 1:10 dilution of the slurry in de-ionized water (2 mL slurry in $20 \mathrm{~mL}$ DI water) was titrated using a series of $0.1 \mathrm{~mL}$ additions of $\sim 1 \mathrm{M}$ nitric acid added once every four minutes.

The final method was not completely free of issues of reproducibility. The five samples with a history were titrated to within $10 \%$ of the values obtained on the old auto-titrator. The co-precipitated noble metal simulant and the heat-treated version of the co-precipitated noble metal simulant were both titrated by the auto-titrator and the manual titration method. This provided some linkage between results obtained by the two different methods. 
WSRC-TR-2005-00285

Revision 0

This page intentionally left blank. 


\subsection{RESULTS}

The results related to the preparation of the simulants are given in this section. The four simulants were given short-hand names as follows:

- TNM simulant to be trimmed with noble metals

- TNM-HT simulant to be trimmed with noble metals after heat-treatment

- CNM simulant with co-precipitated noble metals

- CNM-HT simulant with co-precipitated noble metals that has been heat-treated

TNM-HT was made by heat-treating the TNM simulant. CNM-HT was made from the CNM simulant.

\subsection{Precipitation of Noble Metals}

Samples of the sludge and various supernate streams were analyzed during preparation of the CNM simulant. All recipe ingredients, except for one decanting, were still in the precipitation vessel up until the point where the slurry was transferred to the CUF mixing tank for washing. A slurry sample was taken following washing of the co-precipitated solids. Samples were also taken of the decanted supernate before washing, of the seven 8-L carboys of permeate recovered during cross-flow filtration washing, and of the final supernate decanted after washing. The finished slurry was sampled after all additions had been made. These analytical results are covered in this section.

The first results obtained for the slurry following washing in the CUF are given in Table 1 . The units are parts per billion, i.e. nanograms element per gram slurry. The results are compared to a recipe prediction based on the quantities of the materials added in the recipe and the mass of the slurry following washing.

Table 1. Post-Wash ICP-MS CNM Slurry Analysis

\begin{tabular}{|l|c|c|c|c|}
\hline Element & $\begin{array}{c}\text { ICP-MS } \\
\text { ng/g }\end{array}$ & $\begin{array}{c} \pm 20 \% \text { Uncertainty } \\
\text { ng/g }\end{array}$ & $\begin{array}{c}\text { Recipe Prediction, } \\
\text { ng/g }\end{array}$ & $\begin{array}{c}\text { Met } \\
\text { Expectations? }\end{array}$ \\
\hline $\mathrm{Ag}$ & 43,900 & 8,780 & 46,000 & Yes \\
\hline $\mathrm{Ba}$ & 70,300 & 14,100 & 76,800 & Yes \\
\hline $\mathrm{Cd}$ & 271,000 & 54,200 & 292,000 & Yes \\
\hline $\mathrm{La}$ & 64,800 & 13,000 & 61,600 & Yes \\
\hline $\mathrm{Pd}$ & 11,100 & 2,220 & 6,120 & No \\
\hline $\mathrm{Rh}$ & 11,300 & 2,260 & 11,800 & Yes \\
\hline $\mathrm{Ru}$ & 37,700 & 7,540 & 44,200 & Yes \\
\hline $\mathrm{Zr}$ & 12,700 & 2,540 & 16,200 & Maybe \\
\hline
\end{tabular}

Most of the measured results fall within one standard deviation, i.e. $\pm 20 \%$, of the recipe predictions. All results other than for palladium fall within two standard deviations of the predictions. Palladium just missed being within two sigma of the prediction, and it is also the least concentrated species. Values higher than the recipe prediction are not credible indicators of the actual concentration, since the gravimetric uncertainty of the chemical additions is far less than the analytical uncertainty. The zirconium precipitate may not have been fully dissolved by the aqua regia preparation.

Nine aqueous streams were removed from the slurry before, during, and immediately following washing. These were checked for noble metals losses, Table 2. 
Table 2. Noble Metal Concentrations in Removed Aqueous Streams

\begin{tabular}{||l|c|c|c|c||}
\hline & Volume, $\mathrm{L}$ & $\mathrm{Pd}, \mu \mathrm{g} / \mathrm{L}$ & $\mathrm{Rh}, \mu \mathrm{g} / \mathrm{L}$ & $\mathrm{Ru}, \mu \mathrm{g} / \mathrm{L}$ \\
\hline Pre-wash decant & 9.0 & $<20$ & $<20$ & 4.65 \\
\hline Wash 1 & 8.164 & $<0.1$ & 0.447 & 2.74 \\
\hline Wash 2 & 8.136 & $<0.1$ & 0.568 & 3.67 \\
\hline Wash 3 & 8.159 & $<0.1$ & 0.921 & 2.15 \\
\hline Wash 4 & 8.120 & $<0.1$ & 0.656 & 2.57 \\
\hline Wash 5 & 8.116 & $<0.1$ & 0.538 & 1.34 \\
\hline Wash 6 & 8.073 & $<0.1$ & 0.544 & 1.50 \\
\hline Wash 7 & 8.058 & $<0.1$ & 0.471 & 1.00 \\
\hline Post-wash decant & 4.36 & $<0.1$ & 0.471 & 1.00 \\
\hline
\end{tabular}

The data in Table 2 were used to bound the maximum quantity of the three noble metals lost into the nine aqueous streams by taking the less than values as upper bounds. These bounding mass losses were compared to the masses of the three noble metals added to the slurry in the recipe. The results are given in Table 3 in terms of micrograms. The bounding masses were divided by the recipe masses to compute the maximum percentages of the added noble metal masses that might have been lost to the removed streams.

Table 3. Bounding Noble Metal Mass Losses During Sludge Preparation

\begin{tabular}{|l|c|c|c|}
\hline & $\mathrm{Pd}$ & $\mathrm{Rh}$ & $\mathrm{Ru}$ \\
\hline Maximum $\mu \mathrm{g}$ lost & 186 & 216 & 170 \\
\hline Max. \% of recipe lost & 0.20 & 0.12 & 0.024 \\
\hline
\end{tabular}

The data indicate that the three noble metals were successfully precipitated, i.e. virtually none lost to the aqueous streams. These results do not, however, prove that some fraction of the noble metals had not precipitated onto the mixing tank equipment surfaces, though the efforts mentioned previously were designed to minimize this.

The final CNM simulant slurry was sampled and analyzed by ICP-MS. Analysis was made on a driedsolids basis. The dried solids were dissolved using an aqua regia preparation. The results are given in Table 4.

Table 4. Final CNM Slurry Noble Metal Analysis

\begin{tabular}{|c|c|c|c|}
\hline & Pd, wt. \% & Rh, wt. \% & Ru, wt. \% \\
\hline Original Target & 0.0040 & 0.0077 & 0.029 \\
\hline ICP-MS ( $\pm 20 \%)$ & $0.0045 \pm 0.0009$ & $0.0078 \pm 0.0016$ & $0.0242 \pm 0.0048$ \\
\hline Final Prediction & 0.0041 & 0.0079 & 0.0296 \\
\hline As expected? & Yes & Yes & Yes \\
\hline
\end{tabular}

Target and prediction values were updated to match the units of the ICP-MS results. These are also the units typically used in trimmed noble metal calculations. The final recipe prediction was about $3 \%$ higher than the original target for all three noble metals because of small changes that were made to the recipe during preparation to account for losses, e.g. slurry not recovered from the cross-flow filter unit. 
It was recognized that using co-precipitated noble metals instead of trimmed noble metals would present certain challenges. The primary one of these was controlling the precise quantities of the noble metals present in a SRAT simulation. Trimmed noble metals are added directly to the SRAT, so that the quantity of each noble metal present during the simulation is precisely known. The noble metal concentration of the co-precipitated noble metal simulant can not be known with equal precision. This is due to the inherent limitations of analytical methods.

The ICP-MS analytical results, plus the reported measurement uncertainties, along with the simulant preparation recipe information were used to determine a likely range of concentrations for the noble metals as described in the next paragraphs. The reported measurement uncertainty of $\pm 20 \%$ was taken as one standard deviation.

Ruthenium might be present at roughly $65 \%$ of the recipe prediction if the actual concentration measured were $20 \%$ lower than the number given in Table 4 . Palladium and rhodium might have been $87 \%$ and $79 \%$ of the recipe predictions if their actual concentrations were $20 \%$ lower than measured. $20 \%$ less ruthenium than that reported in the washed slurry equated to $68 \%$ of the amount expected by the recipe prediction, while $20 \%$ less rhodium in the washed slurry was $77 \%$ of the recipe prediction. There was no credible evidence that any of the three noble metals were added in excess of the recipe prediction for their concentrations.

The largest one standard deviation range on the three noble metals was deemed sufficient to bound the likely concentrations of the three noble metals from below, while $100 \%$ of the final recipe prediction was deemed sufficient to bound the likely concentrations of the three noble metals from above. It was decided to test the noble metal-free simulant with noble metals trimmed to both ends of this range.

The likelihood of ruthenium actually being outside of the $65-100 \%$ range was determined to be about $23 \%$, while the likelihood of either rhodium or palladium being outside this range was estimated to be less than $15 \%$. This took into account both the slurry sample after washing and the final slurry sample results, i.e. data pooling, but took no credit for the nine aqueous phase samples that showed negligible losses from the recipe. The low noble metal SRAT test could have been done at even lower fractions of the recipe predicted noble metal concentrations than 65\%. This ran the risk, however, of producing an overly wide range of hydrogen generation values between the $100 \%$ and low tests with which to potentially bracket the co-precipitated noble metal hydrogen generation test results.

\subsection{Elemental Analysis}

ICP-AES analyses were made on both recipes, TNM and CNM. Analyses were made on the original slurries, and again on the heat-treated version of the no noble metal simulant, TNM-HT. An analysis of TNM-HT was necessary because the simulant included a significant fraction of material recovered from samples and other aliquots of the original slurry. It was necessary to ensure that its composition had remained consistent with TNM. Calcined elemental wt. \%'s at $1100^{\circ} \mathrm{C}$ for the three analyzed sludge samples are given in Table 5. A sum of oxides is also given assuming no change in oxidation state for the elements in the sludge, e.g. Fe(III) and Mn(IV). 
Table 5. Calcined Elemental Composition of the Starting Sludges

\begin{tabular}{|l|c|c|c||}
\hline & TNM & TNM-HT & CNM \\
\hline $\mathrm{Ag}$ & 0.031 & 0.063 & $<0.1$ \\
\hline $\mathrm{Al}$ & 9.23 & 8.93 & 8.13 \\
\hline $\mathrm{Ba}$ & 0.063 & 0.061 & 0.059 \\
\hline $\mathrm{Ca}$ & 2.29 & 2.45 & 2.08 \\
\hline $\mathrm{Cd}$ & 0.114 & 0.138 & 0.085 \\
\hline $\mathrm{Ce}$ & 0.129 & n.o. & 0.122 \\
\hline $\mathrm{Cr}$ & 0.214 & 0.201 & 0.216 \\
\hline $\mathrm{Cu}$ & 0.037 & 0.038 & 0.034 \\
\hline $\mathrm{Fe}$ & 24.6 & 23.7 & 24.6 \\
\hline $\mathrm{Gd}$ & 0.065 & n.a. & 0.063 \\
\hline $\mathrm{K}$ & 0.266 & 0.320 & 0.279 \\
\hline $\mathrm{La}$ & 0.051 & n.a. & 0.054 \\
\hline $\mathrm{Li}$ & 0.14 & 0.11 & n.a. \\
\hline $\mathrm{Mg}$ & 2.1 & 2.1 & 1.8 \\
\hline $\mathrm{Mn}$ & 5.22 & 5.22 & 5.13 \\
\hline $\mathrm{Mo}$ & $\mathrm{n} .0$. & 0.059 & 0.059 \\
\hline $\mathrm{Na}$ & 18.9 & 18.1 & 19.8 \\
\hline $\mathrm{Ni}$ & 1.40 & 1.29 & 1.31 \\
\hline $\mathrm{P}$ & 0.52 & 0.57 & n.a. \\
\hline $\mathrm{Pb}$ & 0.006 & $<0.010$ & 0.002 \\
\hline $\mathrm{S}$ & 0.20 & 0.22 & 0.38 \\
\hline $\mathrm{Sb}$ & 0.132 & 0.069 & n.a. \\
\hline $\mathrm{Si}$ & 0.56 & 0.98 & 0.51 \\
\hline $\mathrm{Sn}$ & $<0.2$ & 0.106 & 0.074 \\
\hline $\mathrm{Sr}$ & 0.51 & 0.52 & 0.49 \\
\hline $\mathrm{Ti}$ & 0.030 & 0.027 & 0.022 \\
\hline $\mathrm{Zn}$ & 0.051 & 0.135 & 0.227 \\
\hline $\mathrm{Zr}$ & 0.007 & 0.011 & 0.005 \\
\hline $\mathrm{N} \mathrm{oxides}$ & 98.6 & 98.4 & 97.1 \\
\hline & & & \\
\hline
\end{tabular}

n.a. = not available

Results were generally consistent. A few minor elements were not analyzed in TNM-HT, since the main purpose was to ensure that the heat-treated material generally matched the TNM composition. The slightly higher aluminum content of the TNM simulant compared to CNM simulant is potentially real. Aluminum oxide was one of the components added after cross-flow filtration washing of the precipitated solids. It was difficult to make identical adjustments to the two recipe preparations at this point due to analytical uncertainties.

\subsection{Analysis of Anions}

Samples of all four sludge simulants were analyzed for anions. Results are given in Table 6. 
Table 6. Anion Data for Starting Sludges

\begin{tabular}{|l|r|r|r|r||}
\hline \hline mg/kg slurry & TNM & TNM-HT & CNM & CNM-HT \\
\hline Nitrite & 14,200 & 16,800 & 14,000 & 15,700 \\
\hline Nitrate & 10,100 & 12,000 & 10,900 & 11,000 \\
\hline Chloride & 180 & 200 & 230 & 200 \\
\hline Sulfate & 1420 & 950 & 1640 & 1570 \\
\hline Phosphate & 740 & 110 & 780 & $<100$ \\
\hline
\end{tabular}

Measured nitrite went up by 11-16\% during heat-treatment as soluble solids, see Table 7 , went down. This must be cumulative analytical error on both the before and after nitrite numbers, since the only source of nitrogen other than nitrite was nitrate No corresponding decrease in nitrate was seen. Water soluble phosphate decreased significantly during heat-treatment, suggesting that it may have been converted to a less soluble form. Sulfate values were reported with large uncertainties, but are included for completeness. The uncertainty relates to the performance of this particular IC column with anions with a negative two charge.

\subsection{Analysis of Solids, Density, and pH}

Wt. \% solids, $\mathrm{pH}$, and density data were obtained on the original and heat-treated versions of both slurries. Averages of the duplicate results are given in Table 7.

Table 7. Wt. \% Solids, Density, and pH Data for Starting Sludges

\begin{tabular}{|l|r|r|r|c|}
\hline & TNM & TNM-HT & CNM & CNM-HT \\
\hline Total Solids & 18.55 & 18.89 & 18.31 & 18.66 \\
\hline Insoluble Solids & 11.59 & 12.09 & 11.05 & 11.71 \\
\hline Soluble Solids & 6.96 & 6.80 & 7.27 & 6.93 \\
\hline Calcined Solids & 14.05 & 14.28 & 13.95 & 14.06 \\
\hline Density & 1.13 & 1.10 & 1.14 & 1.12 \\
\hline $\mathrm{pH}$ & 11.7 & 11.8 & 12.0 & Not obtained \\
\hline
\end{tabular}

Heat-treatment seemed to lead to slightly higher total and insoluble solids and lower soluble solids. There may have been some small amount of evaporation loss during heat-treatment that contributed to this. Density and $\mathrm{pH}$ did not seem to be affected significantly by heat-treatment.

\subsection{Total Inorganic Carbon Analysis}

Every effort was made to bring the TNM and CNM simulant compositions, except for the noble metals, to essentially the same point by the end of the preparation. This was generally successful for the major species. Samples of the TNM and CNM simulants were submitted to ADS for total inorganic carbon, TIC, analysis in 2004. Values of 2100 and $2060 \mathrm{mg} / \mathrm{kg}$ TIC were obtained for CNM and TNM simulants respectively. Based on these TIC values, no adjustment was made to bring the two simulants into closer agreement.

Sets of triplicate samples of all four simulants were submitted for a fresh determination of TIC in 2005. This followed the development of a new method for handling simulant slurry samples in this analysis. The revised submission procedure calls for submitting two samples of the undiluted slurry, "Slurry-1" and "Slurry-2" in Table 8, along with a third sample diluted ideally into the range of 50-75 mg/L TIC. 
Results for these third samples, "Diluted Slurry (adj)" in Table 8, were converted back to an original slurry basis by multiplying by the dilution ratio.

Table 8. 2005 TIC Data for Starting Sludges

\begin{tabular}{|l|c|c|c|c|}
\hline \hline mg C/kg slurry & TNM & TNM-HT & CNM & CNM-HT \\
\hline Slurry-1 & 2160 & 2050 & 2410 & 2500 \\
\hline Slurry-2 & 2280,2090 & 1950 & 2420 & 2450 \\
\hline Diluted Slurry (adj) & 2290 & 1870 & 2480 & 2470 \\
\hline Average & 2210 & 1960 & 2440 & 2470 \\
\hline
\end{tabular}

Two results were obtained for one of the no noble metal slurry samples, 2280 and 2090, because one analysis had a fairly high \% RSD compared to the other samples. Since all results for the TNM sample ultimately fell in a narrow band, none of the reported data were rejected. The 2005 values for TNM and TNM-HT bracket the 2004 result of $2060 \mathrm{mg} / \mathrm{kg}$. The results for the co-precipitated noble metal simulant, however, were about 17\% higher than in 2004.

A real difference is suspected between the TNM/TNM-HT and the CNM/CNM-HT simulants due to all of the additional data obtained in 2005. Based on repeated analyses of the simulants, the difference in the TIC values has been consistent through the entire program. This difference is real and is not attributed to random uncertainty or bias.

TIC in both simulants was considerably higher than in the targeted SB3 composition. A value of about $1200 \mathrm{mg} / \mathrm{kg}$ TIC was targeted based on the Tank 40 sample. The CETL SB3 simulants contained about $1100 \mathrm{mg} / \mathrm{kg}$ TIC. Step 6 of the simulant preparation method combined with the $\mathrm{Na}_{2} \mathrm{CO}_{3}$ addition in step 11 led to the higher than expected TIC values. No credit was taken in the original SB3 recipe for precipitation of significant insoluble carbonate in step 6. Apparently about $800-1200 \mathrm{mg} / \mathrm{kg}$ TIC were brought into the slurry at this point. A lower bound of $1220 \mathrm{mg} / \mathrm{kg}$ TIC can be placed on the analytical results based on the final recipe addition of sodium carbonate in step 11. It appears that approximately $100 \%$ of the targeted TIC was introduced in each of the two steps, leading to roughly $200 \%$ of the targeted TIC in the final slurry.

\subsection{Measurement of Base Equivalents}

Base equivalent molarities of slurry samples were measured for all four versions. The results are given in Table 9. Results from the manual titration method tended to be about $0.03-0.05 \mathrm{M}$ lower than those obtained on the auto-titrator at $\mathrm{pH}$ 7, i.e. within 7\%. Manual titration results were more uncertain and had fewer significant figures.

Table 9. Base Equivalents Measurements on Starting Slurries

\begin{tabular}{|l|c|c|c|c|}
\hline M at pH 7 & TNM & TNM-HT & CNM & CNM-HT \\
\hline Auto-titrator & 0.815 & - & 0.821 & 0.690 \\
\hline Manual Titration & 0.79 & 0.69 & 0.77 & 0.65 \\
\hline \hline
\end{tabular}

The titration results were all significantly higher than the target molarity of $0.43 \mathrm{M}$. They were also higher than the typical molarity of CETL SB3 simulants, which have been in the range of $0.55-0.60 \mathrm{M}$. The $\mathrm{NaOH}$ addition in step 11 of the simulant preparation method in section 2.1 was sufficient to produce $0.43 \mathrm{M}$ base equivalents. The calculated addition did not take credit for any other titratable species that 
might already be present, e.g. carbonates, hydroxides of aluminum, etc. The other titratable species apparently contributed about $50 \%$ of the total base equivalent molarity of the two fresh simulants. The elevated base equivalents may have been influenced by the TIC result, which was about twice what was targeted, but this is not the only reason that the base equivalents were higher than expected.

The TNM-HT simulant had not been prepared when the auto-titrator failed. The manual titration result for TNM was on the heel of the recipe combined with unused sample, etc. and may have been slightly different from the original TNM slurry run on the auto-titrator. Heat-treatment produced a distinct drop in base equivalents of about 0.10-0.13M. This prompted a follow-up investigation, section 3.7.

Based on the analytical data, it is recommended that $\mathrm{Na}_{2} \mathrm{CO}_{3}$ and $\mathrm{NaOH}$ additions be delayed in future uses of this recipe protocol until the TIC and base equivalents are checked. Then add any $\mathrm{Na}_{2} \mathrm{CO}_{3}$ that may be required to reach the TIC target. It is further recommended that the equilibration time between the slurry and the carbonate wash solution be determined, so that replicate preparations of a recipe will produce the same fraction of insoluble carbonates. If any $\mathrm{Na}_{2} \mathrm{CO}_{3}$ needs to be added to reach the TIC target, then the base equivalents should be rechecked before adding any $\mathrm{NaOH}$. It is also recommended that $\mathrm{Al}(\mathrm{OH})_{3}$ be used instead of $\mathrm{Al}_{2} \mathrm{O}_{3}$ in step 9. White solids believed to be $\mathrm{Al}_{2} \mathrm{O}_{3}$ were observed in dilutions of the slurry samples during TIC measurement.

Finally, it is recommended that a method be developed to adjust the addition masses in step 9 whenever the cross-flow filter is used for washing. Using the cross-flow filter involves moving the slurry between tanks with subsequent losses of slurry mass. One solution would be to make these additions while the slurry is still in the cross-flow filter mixing tank, rather than after it has been transferred back to the preparation vessel. The reason for this is that $100 \%$ recovery of the insoluble solids out of the cross-flow filter unit is not possible. Consequently, these four masses may need to be adjusted down to keep the ratios of the step 9 species masses correct relative to the step 4 species masses. The adjustments are sensitive to analytical uncertainties, which are larger than gravimetric uncertainties.

\subsection{Heat Treatment and Base Equivalents}

There was a second step to simulant preparation. It was recognized that real waste has spent decades in the tank farm. The structure and speciation of the insoluble solid species were expected to be altered over time. The precise beginning and ending points of such changes are not known. A decision was made to subject a portion of both simulants to a period of time at elevated temperature. The purpose of this heattreatment was to qualitatively capture some of the changes that could occur during aging in the tank farm.

There were several reasons for investigating this phenomenon. First, during the SRAT cycle, the simulant is taken to $93^{\circ} \mathrm{C}$ over a $40-60$ minute period before adding nitric acid. Potentially, during this period, and perhaps during nitric acid addition itself, the solids in the sludge could be changing into less basic forms that require less acid to process. In this case the acid calculations prepared for bench-scale SRAT simulations would lead to greater than necessary additions of acid relative to the stoichiometric requirement. The second reason is related to potential disruptions in processing during acid addition that could put extended time at elevated temperature on a simulant relative to other runs intended to be comparable in some respect. This in situ heat-treatment could invalidate later comparisons. Third, it is still unknown whether heat-treating the simulants made by the older preparation recipes would impact the base equivalent molarity.

A second portion of the CNM simulant slurry was subjected to heat-treatment as a follow-up study. A series of samples was taken during heat-treatment for titration. The sampling frequency was high toward the beginning of the heat-treatment process, since it was not known how quickly the change might take 
place. Samples were placed in an ice bath as soon as they were pulled in an attempt to halt further significant reactions from taking place. Titrations of these samples were all by the manual method.

The titration molarity data from the second heat-treatment of the co-precipitated noble metal simulant at pH 7 and pH 5.5 are given in Figure 1. Separate molarity axes were used for the two pH endpoints.

Figure 1. Heat-Treatment Titration Data Summary

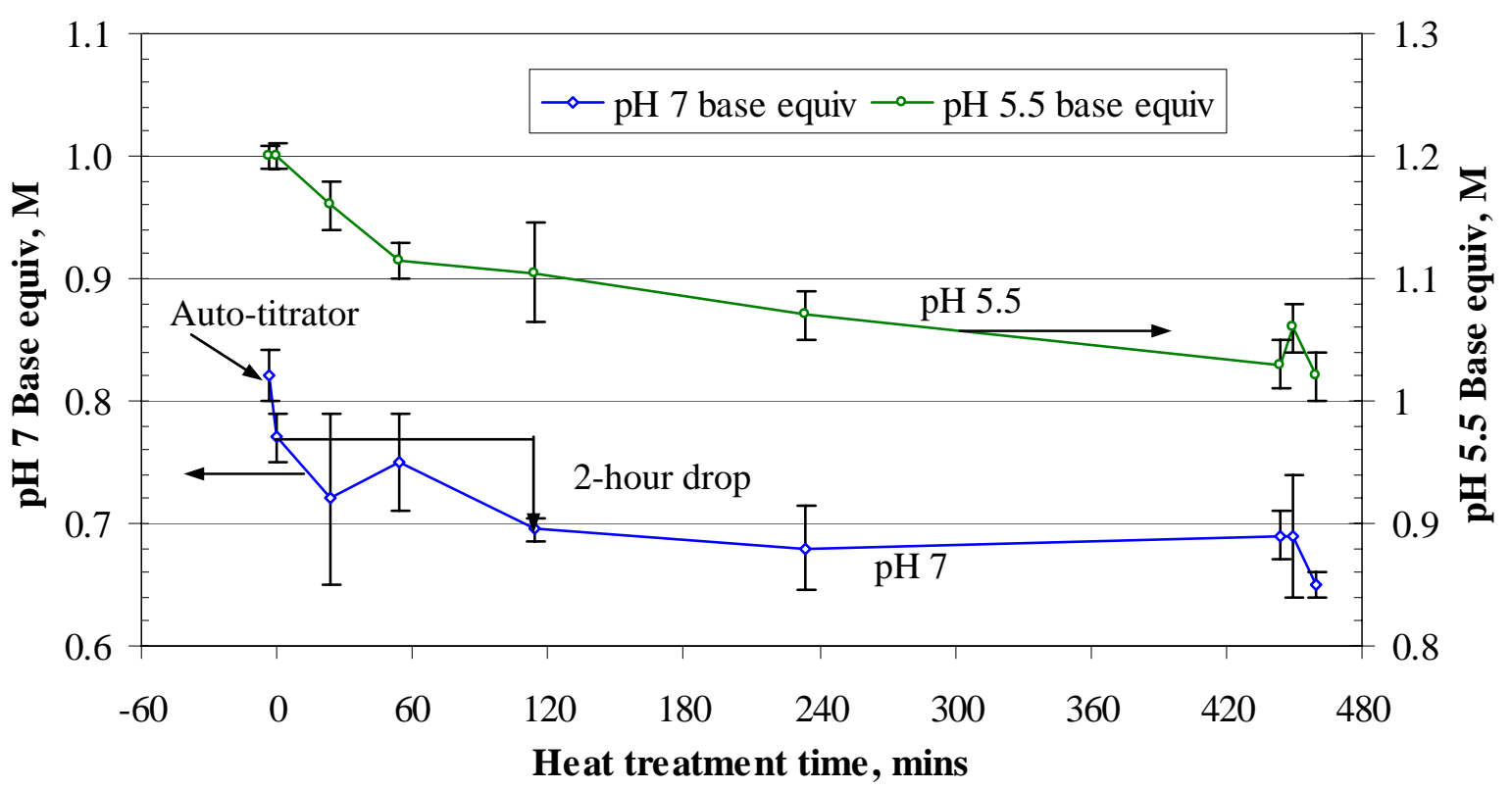

Error bars are estimates of uncertainty based on multiple titrations of the same sample and the range of molarity values that were found at that $\mathrm{pH}$. The data at zero minutes includes both a manual titration of the starting sludge and an auto-titration of the starting sludge. The data at 450 minutes includes manual titration data for the first heat-treatment in addition to the result from a quenched sample at the end of the second heat-treatment plus a second result from the end of the second heat-treatment on material that was allowed to cool naturally to room temperature (not quenched in the ice bath). The low $\mathrm{pH} 7$ value was from the first heat-treatment.

It appears that much of the change occurs in the first two hours, especially at $\mathrm{pH} 7$. This means that the base equivalents probably fall somewhat prior to the start of acid addition even in a normal SRAT experiment. This is pertinent to one of the scoping runs in the form of noble metal test sequence, named TNM, in Koopman (2005b). The SRAT lid broke during acid addition and had to be replaced. This left the slurry at elevated temperature for additional time relative to the other tests. The base equivalents drop in the scoping run with the broken lid could have easily been $\sim 0.06 \mathrm{M}$. This would have caused the acid stoichiometric factor to shift to a higher number than targeted.

The pH 7 and pH 5.5 curves track each other fairly well. These are the two end points that have traditionally been measured in SRNL. The raw titration curve data was used to construct two additional curves for endpoints of $\mathrm{pH} 7.5$ and 5.0, Figure 2. 
Figure 2. Effect of Heat-treatment at Alternate pH Endpoints

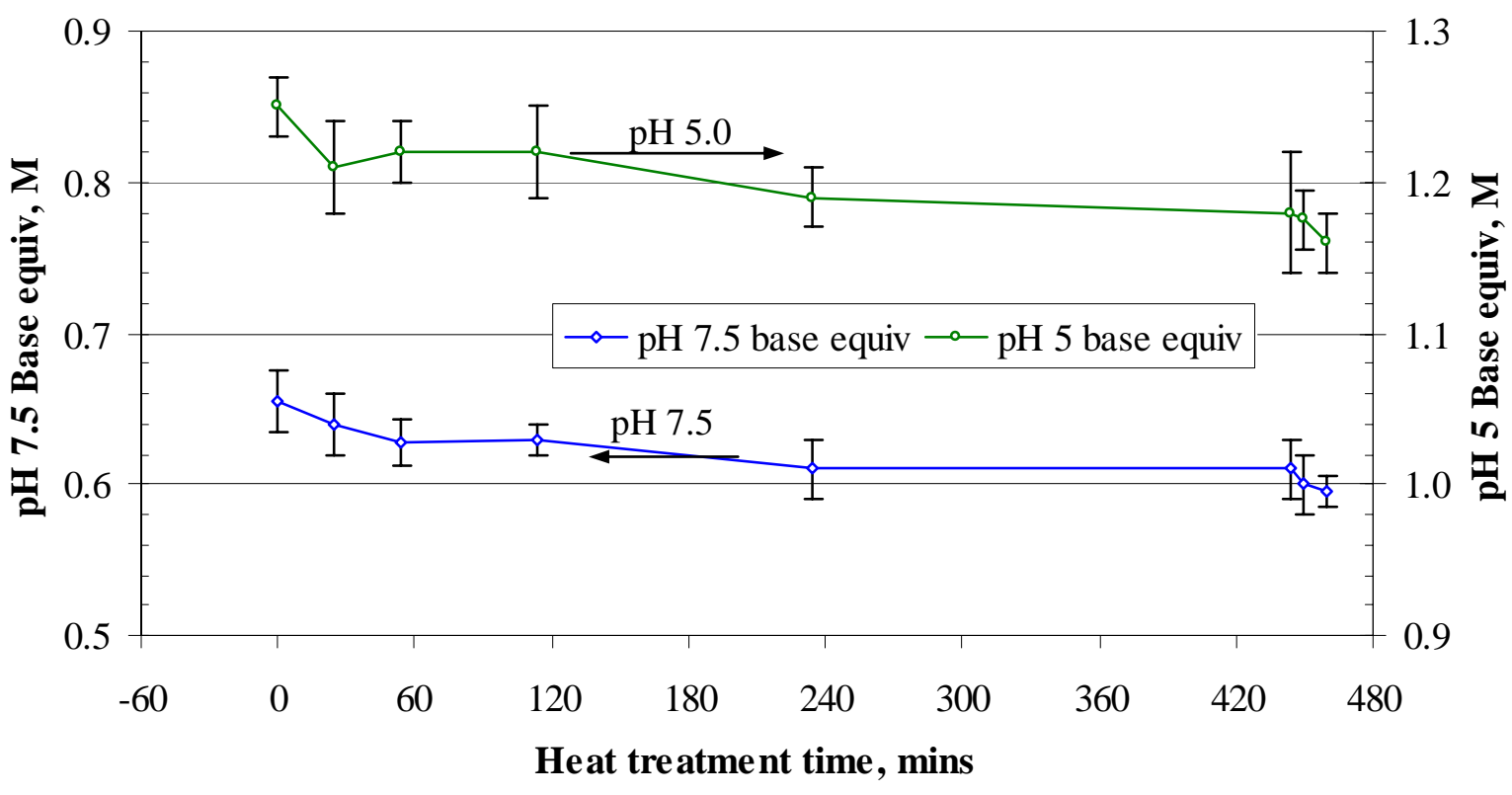

The most noteworthy feature of these traces in Figure 2 is that the $\mathrm{pH} 7.5$ molarity changed by only about half as much as the $\mathrm{pH} 7$ and $\mathrm{pH} 5.5$ molarity did in Figure 1. Base equivalents changed by over $0.1 \mathrm{M}$ at $\mathrm{pH} 5.5$ and 7 over the course of the 7.5 hour heat-treatment. The change in the $\mathrm{pH} 7.5$ base equivlanets was only about $0.05 \mathrm{M}$. A pH 7.5 endpoint was selected for study because most of the titration data were reproducible and relatively method independent down to $\mathrm{pH}$ 7.5.

Most titration issues arose at pH's lower than 7.5. The most common one was a separation in the curves for repeated titrations on the same sample. This is illustrated in Figure 3. 
Figure 3. Example of Manual Titration Data

Co-ppt SB3 Sludge with noble metals, after 54 mins

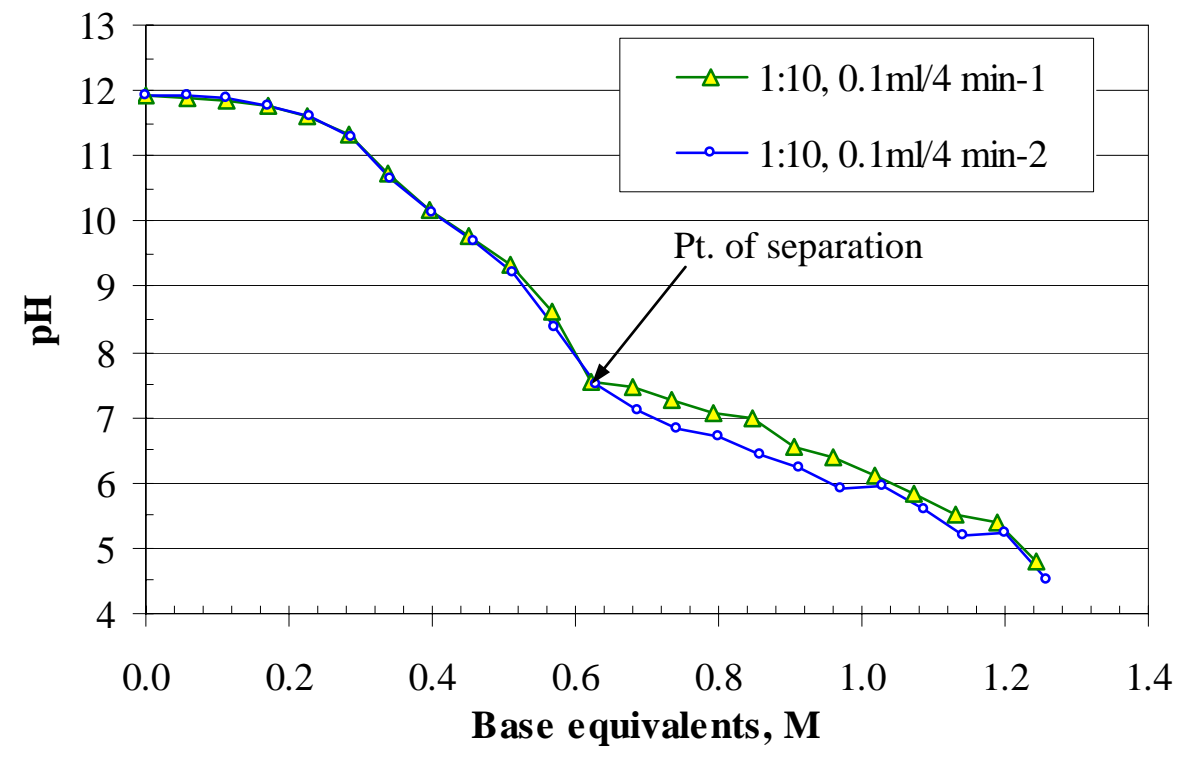

The two replicate titrations tracked each other remarkably well down to about $\mathrm{pH}$ 7.5. After that the two curves separated until $\mathrm{pH}$ fell below 6, upon which they closed back together. Separations occurred at different $\mathrm{pH}$ values with different samples. Almost all samples titrated, however, were consistent from the initial $\mathrm{pH}$ down to less than $\mathrm{pH} 8$.

The change in $\mathrm{pH} 7$ base equivalents during heat-treatment of the two new SB3 simulants occurred in all three instances. It was essentially the same change all three times, or about a $0.12 \mathrm{M}$ reduction. It is not yet known whether or not the thermally-induced change in base equivalents could occur simultaneously with neutralization during acid addition in the SRAT either with simulants or real waste. The SRAT data in Koopman (2005b) seem to indicate that not all of the base equivalents change due to heat-treatment occurs during processing. This heat-treatment test has not been applied to simulants prepared by the traditional recipe, e.g. the CETL simulants used for SB3 and Sludge Batch 4 flowsheet testing. This should be checked to see if similar changes occur in those simulants. 


\subsection{CONCLUSIONS}

Parallel preparations of two new sludge simulants to support the hydrogen generation program were successfully completed. Identical steps were used except that one simulant had dissolved palladium, rhodium, and ruthenium present during the precipitation of the insoluble solids while the other did not. Portions of both sludge simulants were held at $97^{\circ} \mathrm{C}$ for about eight hours to qualitatively simulate the effects of long term storage on particle morphology and speciation.

The following conclusions were drawn:

- The first preparation of a waste slurry simulant with co-precipitated noble metals was successful, based on the analytical data obtained. It appears that $99+\%$ of the noble metals were retained in the simulant.

- Better control of carbonate, hydroxide, and post-wash trim chemical additions is needed before the new method of simulant preparation will be as reproducible as the old method.

- Visual observations were made of very obvious differences in rheological properties. The original co-precipitated simulants were very viscous compared to the traditional SB3 simulant.

- The heat-treatment step made the co-precipitated simulants less viscous, though still more viscous than the traditional SB3 simulant. The apparent viscosity probably has no significant impact on hydrogen generation.

- The approach of using a $97^{\circ} \mathrm{C}$ heat-treatment step to qualitatively simulate tank farm aging may not be optimal. A significant change in the base equivalent molarities of both simulants was observed during heat-treatment.

- Heat-treatment appeared to make phosphates insoluble in water.

The lessons learned in this study should be valuable in future phases of the hydrogen generation rate program as well as to the Simulant Development Program and other programs performing simulations of the DWPF Chemical Processing Cell. 
WSRC-TR-2005-00285

Revision 0

This page intentionally left blank. 


\subsection{RECOMMENDATIONS/PATH FORWARD}

The following recommendations came out of the simulant preparation work:

- Washed slurry should be checked for TIC and base equivalents before calculating the final trim chemical additions of sodium carbonate and sodium hydroxide. If any $\mathrm{Na}_{2} \mathrm{CO}_{3}$ needs to be added to reach the TIC target, then the base equivalents should be rechecked before adding any $\mathrm{NaOH}$.

- Final insoluble trim chemicals should be added to the slurry in the CUF mixing tank, since significant slurry is lost in the CUF equipment. Adding the chemicals here would keep them in the correct proportion relative to the precipitated insoluble solids.

- A composite wash water and decanted supernate sample should be prepared containing proportionally weighted masses of each aqueous stream removed during preparation of a coprecipitated noble metal simulant. This sample should then be checked for noble metal losses. This would reduce the sample load, while still confirming that there was no significant noble metal loss.

- A study of the impact of heat-treatment on existing simulants should be undertaken. If there is a shift in base equivalents, then SRNL acid stoichiometries may be biased relative to real waste. The study should ultimately be extended to real wastes to see if base equivalents changes during heating there as well.

- The equilibration time between the slurry and the carbonate wash solution should be determined, so that repeated preparations of a recipe produce the same fraction of insoluble carbonates.

- It is also recommended that $\mathrm{Al}(\mathrm{OH})_{3}$ be used instead of $\mathrm{Al}_{2} \mathrm{O}_{3}$. White solids believed to be $\mathrm{Al}_{2} \mathrm{O}_{3}$ were observed in dilutions of the slurry samples during TIC measurement. 


\subsection{REFERENCES}

Baich, M. A., Modified Lab Scale SRAT Findings and Recommendations. SRNL-GPD-2004-00098, Savannah River Site, Aiken, SC 29808 (2004).

Eibling, R. E., Impact of Simulant Production Methods on the Physical Properties of DWPF Sludge Batch 3 Simulant. WSRC-TR-2004-00578, Savannah River Site, Aiken, SC 29808 (2005).

Fellinger, T. L., and D. C. Koopman, Hydrogen Generation for Sludge Receipt and Adjustment Tank (SRAT) and Slurry Mix Evaporator (SME), WSRC-RP-2004-0028 (TT\&QAP), Savannah River Site, Aiken, SC 29808 (2004).

Koopman, D. C., Review of Catalytic Hydrogen Generation in the Defense Waste Processing Facility (DWPF) Chemical Processing Cell (U). WSRC-TR-2002-00334, Savannah River Site, Aiken, SC 29808 (2004).

Koopman, D. C., Analytical Study Plan for Hydrogen Generation for Sludge Receipt and Adjustment Tank (SRAT) and Slurry Mix Evaporator (SME) (U). SRNL-GPD-2004-00060, Savannah River Site, Aiken, SC 29808 (2004).

Koopman, D. C., and M. A. Baich, Effect of Mercury-Noble Metal Interactions on SRAT Processing of SB3 Simulant (U). WSRC-TR-2004-00548, Savannah River Site, Aiken, SC 29808 (2005a).

Koopman, D. C., DWPF Hydrogen Generation Study - Form of Noble Metal SRAT Testing (U). WSRCTR-2005-00286, Savannah River Site, Aiken, SC 29808 (2005b).

Pareizs, J. M., T. L. Fellinger, and D. R. Click, Characterization of the March 2004 Tank 40 (Sludge Batch 3) Dip Samples. WSRC-TR-2004-00208, Savannah River Site, Aiken, SC 29808 (2004). 


\subsection{ACKNOWLEDGEMENTS}

The author is indebted to Terri Fellinger for her help in coordinating the hydrogen generation study activities, monitoring resources and spend out, and providing feedback as needed. The author acknowledges the contributions of David Best, Jennifer Jansen, and Pat Toole for their work on sample analysis. Additional analytical support came from the Analytical Development Section under the direction of John Young (TIC), and Mike Whitaker, William Boyce, and Curtis Johnson (ICP-MS). Mark Baich oversaw the experimental preparation of the co-precipitated noble metal simulant. Ned Bibler reviewed the plans and data obtained during preparation of the co-precipitated noble metal simulant, especially the ICP-MS results. Thanks are also due to Joe Wheeler and Frances Williams, along with Tony Burckhalter, Jon DuVall, Sammie King, Debbie Marsh, Irene Reamer, Vickie Williams, and Phyllis Workman for their support during the experimental phase. 


\section{Distribution:}

E. W. Holtzscheiter, SRNL

D. A. Crowley, 999-W

S. L. Marra, 999-W

T. B. Calloway, 999-W

N. E. Bibler, SRNL

C. M. Jantzen, SRNL

G. C. Wicks, SRNL

J. R. Harbour, 773-42A

C. A. Langton, 773-43A

T. L. Fellinger, SRNL

M. A. Baich, 999-W

C. C. Herman, 773-42A

M. E. Stone, 999-W

J. M. Pareizs, SRNL

C. J. Bannochie, 773-42A

M. J. Barnes, SRNL

M. S. Miller, 704-S

J. E. Occhipinti, 704-S

R. M. Hoeppel, 704-27S

H. H. Elder, 766-H

J. F. Iaukea, 704-30S

J. W. Ray, 704-S

F. A. Washburn, 704-28S

P. M. Patel, 704-27S

R. N. Mahannah, 704-28S

A. B. Sanders, 704-27S

W. B. Van-Pelt, 704-S 